\title{
Hygiene dan Sanitasi Pada Pedagang Makanan Jajanan Murid Sekolah Dasar di Kota Pekanbaru, Riau
}

\author{
Hetty Ismainar ${ }^{1 *}$, Yessi Harnani ${ }^{2}$, Nila Puspita Sari ${ }^{2}$, Kamali Zaman $^{2}$, Hayana $^{2}$, Hasmaini $^{2}$ \\ 1 Program Studi S2 Ilmu Kesehatan Masyarakat, STIKes Hang Tuah Pekanbaru, Riau, J1 Mustafasari No 5 Tangkerang \\ Selatan, Pekanbaru, Riau 28282, Indonesia \\ 2 Program Studi Sarjana Kesehatan Masyarakat, STIKes Hang Tuah Pekanbaru, Riau, Jl Mustafasari No 5 Tangkerang \\ Selatan, Pekanbaru, Riau 28282, Indonesia \\ * Corresponding author: hettyismainar@gmail.com
}

Info Artikel:Diterima 29 Juni 2021 ; Direvisi 14 November 2021 ; Disetujui 18 November 2021

Tersedia online : 3 Februari 2022 ; Diterbitkan secara teratur : Februari 2022

Cara sitasi (Vancouver): Ismainar H, Harnani Y, Sari NP, Zaman K, Hayana H, Hasmaini H. Hygiene dan Sanitasi Pada Pedagang Makanan Jajanan Murid Sekolah Dasar di Kota Pekanbaru, Riau. Jurnal Kesehatan Lingkungan Indonesia [Online]. 2022 Feb;21(1):27-33. https://doi.org/10.14710/jkli.21.1.27-33.

\begin{abstract}
ABSTRAK
Latar belakang: Sanitasi pada makanan merupakan upaya untuk mengamankan dan menyelamatkan agar makanan tetap bersih, aman dan sehat. Masih ditemukan pedagang makanan yang belum memenuhi standar hygienitas terutama pada makanan jajanan anak di Sekolah Dasar (SD). Penelitian ini bertujuan menjelaskan hubungan hygiene dan sanitasi pedagang makanan dilihat dari pengetahuan, personal hygiene, kebersihan peralatan, cara penyajian dan lingkungan.

Metode: Jenis penelitian observasional, desain cross sectional. Pemilihan sampel berjumlah 35 pedagang makanan pada sebelas SD di Kota Pekanbaru dengan purposive sampling. Penelitian dimulai bulan JuniAgustus 2019. Instrumen penelitian menggunakan kuisioner terstruktur. Analisis data menggunakan uji univariat dan bivariat dengan uji chi-square pada tingkat kepercayaan $95 \%$.

Hasil: Masih terdapat 18 orang $(51,4 \%)$ hygiene dan sanitasi makanan dengan kategori rendah $(\leq 700)$. Ada hubungan signifikan antara personal hygiene, pengetahuan, kebersihan peralatan, cara penyajian dan lingkungan dengan hygiene dan sanitasi makanan dengan $\rho$-value $\leq 0,05$ dan nilai POR $>1$. Sedangkan untuk kebersihan peralatan merupakan faktor dominan dengan $\mathrm{POR}=8,400(1,829-38,568)$.

Simpulan: Kelima variabel yang diteliti berhubungan dengan hygiene dan sanitasi makanan dan merupakan faktor risiko. Perlu koordinasi. peran aktif dan pengawasan pihak sekolah bersama pemerintah dalam penerapan standar kebersihan, keamanan dan makanan sehat bagi siswa SD di Kota Pekanbaru.
\end{abstract}

Kata kunci: Hygiene dan sanitasi; Makanan Jajanan; Sekolah Dasar

\section{ABSTRACT}

Title: Hygiene and Sanitation of Snack Traders for Elementary School Students in Pekanbaru, Riau

Background: Food sanitation is an effort to secure and save food to keep it clean, and healthy. But there are still food traders who do not use hygiene standards, especially in snacks in elementary schools. The study aimed to describe the correlation between hygiene and sanitation of food vendors seen from the knowledge, personal hygiene, equipment cleanliness, sanitary presentation, and the environment.

Method: It was observational with a cross-sectional design. The sample selection consisted of 35 food traders at eleven elementary schools in Pekanbaru with purposive Sampling. The study was conducted for three months (June-August). The research instrument used a structured questionnaire. The data analysis used univariate and bivariate analysis with chi-square test at 95\% Confidence Interval. 
Result: There are still have 18 (51.4\%) traders whose food hygiene and sanitation are in a low category (Standart <700). There was a significant correlation between, personal hygiene, knowledge, equipment cleanliness, sanitary presentation, and the environment with food hygiene and sanitation with p-value $<0.05$ and $P O R>1$. Meanwhile, equipment hygiene was the dominant factor with POR =8,400 (1,829-38,568).

Conclusion: The five variables studied were related to food hygiene and sanitation as a risk factors. Need coordination. the active role and supervision of the school committee together with the government in implementing hygiene, safety, and healthy food standards for elementary school students in Pekanbaru.

Keywords: Hygiene and sanitation; Snacks; Elementary School

\section{PENDAHULUAN}

Pengolahan makanan yang baik, bersih dan benar akan menghasilkan makanan sehat dan aman untuk dikonsumsi dan syarat konsumsi makanan yang baik berada pada tingkat kematangan, bebas dari pencemaran di tahap produksi serta penyajian. ${ }^{1}$ Makanan yang sangat disukai oleh anak usia SD adalah makanan jajanan ${ }^{2}$ Cerminan kebiasaan anak dalam mengkonsumsi makanan jajanan yang kurang baik tersebut dapat mempengaruhi gizi anak. Kebersihan makanan jajanan dapat berpengaruh terhadap kejadian diare karena penggunaan zat berbahaya dan dapat berakibat pada keracunan makanan. $^{3-6}$

Tingginya resiko keracunan makanan jananan pada anak usia sekolah dikarenakan tingkat pengetahuan anak sekolah dan pedagang yang sangat rendah. Agar anak-anak terhindar dari beragam penyakit seperti diare, schistosomiasis dan demam typoid perlu pengetahuan dalam memilih jajanan yang sehat guna meningkatkan derajat kesehatan anak-anak tersebut. ${ }^{7,8}$

Apabila pola konsumsi jajanan sehat anak sekolah dijaga, maka tumbuh kembangnya akan optimal yang berpengaruh terhadap kualitas anak pada masa yang akan datang. Kejadian diare sebagai dampak konsumsi jajanan bisa ditularkan melalui air yang kurang bersih. Kondisi pasokan air yang buruk dapat membuat anak sekolah terkena air minum yang terkontaminasi oleh bakteri penyakit diare.,

Bila anak belum dibekali dengan pengetahuan yang baik tentang jajanan yang sehat akan dapat menyebabkan foodborne disease. Akibatnya masih sering kita dapatkan jajanan di sekolah yang belum memenuhi syarat kesehatan. Temuan dari data BPOM (Balai Pengawasan Obat dan Makanan) pada tahun 2008-2011, terdapat 40-44\% jajanan tersebut belum memenuhi syarat. ${ }^{11}$

Pada negara berkembang masih ditemukan lebih dari 1500 juta kejadian penyakit karena makanan yang dikonsumsi dan tiga juta diantaranya menyebabkan kematian. Salah satu penyakit yang didertita anak adalah diare dan penyakit diseluruh dunia. ${ }^{12}$ Di Indonesia pernah terjadi Kejadian Luar Biasa (KLB) akibat keracunan makanan dan minuman. Terdapat lebih kurang 1.600 orang terpapar dan diare ini merupakan penyebab Case Fatality Rate (CFR) yang sangat banyak yaitu $1,14 \% .^{13}$
Personal hygiene mengacu pada kebersihan fisik seseorang dan manusia merupakan sumber pontensial mikroba penyebab penyakit. Upaya untuk menghindari kontaminasi jajanan dengan cara menerapkan standar yang tinggi terhadap personal hygiene. Kebersihan peralatan diperoleh dengan cara memilih perlengkapan alat masak yang digunakan untuk mengolah makanan serta menggunakan bahan yang mudah untuk dibersihkan. Sebaiknya bahan dari alat yang digunakan untuk mengolah makanan tersebut tidak menimbulkan reaksi dengan bahanbahan makanan lain yang digunakan. ${ }^{14}$

Syarat penyajian makanan harus menjaga kebersihan, harus diwadahi dengan alat-alat yang bersih serta perilaku dalam penyajian yang harus sehat dan bersih pula. Membiasakan untuk mencuci tangan memakai sabun dapat berguna untuk mencegah penyebaran kuman dan bakteri penyakit diare, infeksi cacing dan lain sebagainya. ${ }^{9}$ Sarana dan lingkungan yang baik harus sesuai dengan standar higiene dan sanitasi, tempat tersebut harus memiliki pembagian ruang, lantai, dinding yang kokoh, ventilasi yang memadai, pencahayaan atau penerangan yang cukup, atap yang kuat, langit-angit yang bebas dari serangga dan vektor pengganggu. ${ }^{15}$

Angka kejadian diare di Kota Pekanbaru 30,4\% mayoritas ditemukan pada anak. ${ }^{16}$ Perlu langkah kongrit dalam pencegahan dan pengawasan pada kualitas makanan jajanan anak sekolah. Tujuan dari penelitian ini adalah guna menjelaskan hubungan hygiene dan sanitasi pedagang jajanan anak dilihat dari aspek pengetahuan, personal hygiene, kebersihan peralatan, cara penyajian dan lingkungan.

\section{MATERI DAN METODE}

Jenis penelitian observasional, desain cross sectional. Populasinya adalah seluruh pedagang makanan jajanan yang berada di Kota Pekanbaru. Pemilihan sampel berjumlah 35 pedagang makanan pada sebelas SD di Pekanbaru dengan menggunakan teknik purposive sampling. Kriteria inkulusi sampel ini berdasarkan banyaknya kasus diare anak yaitu di wilayah Kelurahan Simpang Baru dan pedagang yang berjualan lebih dari 5 tahun. Penelitian dilakukan selama tiga bulan.

Variabel dependen adalah hygiene dan sanitasi makanan, sedangkan variebel independen yaitu: pengetahuan, personal hygiene, kebersihan peralatan, cara penyajian dan lingkungan. Instrumen penelitian 
menggunakan panduan kuisioner terstruktur yang berjumlah 60 pernyataan dengan skala ukur ordinal. Kategori variabel independen yaitu: pengetahuan diberikan skor $1=$ benar dan $0=$ salah. Persentase pengetahuan membandingkan total skor dibagi dengan skor maksimal dikali $100 \%$. Kategori $0=$ rendah jika $\leq$ mean 8, kategori 1=tinggi jika> mean 8. Variabel personal hygiene $0=$ Rendah, jika $\leq$ mean 3 dan $1=$ Tinggi, jika $>$ mean 3. Variabel kebersihan peralatan $0=$ Rendah, jika $\leq$ mean 3 dan $1=$ Tinggi, jika $>$ mean 3. Variabel cara penyajian $0=$ Rendah, jika $\leq$ mean 4 dan 1 = Tinggi, $>$ mean 4 . Variabel lingkungan $0=$ Rendah, jika $\leq$ mean 3 dan 1 = Tinggi, > mean 3 .

Variabel dependen yaitu hygiene dan sanitasi makanan yang menggunakan indikator Keputusan Menteri Kesehatan (Kepmenkes) dengan No:942/Menkes/SK/VII/2003 yaitu pedoman persyaratan hygiene sanitasi jajanan yaitu $0=$ rendah
$($ skor $\leq 700)$ dan $1=$ tinggi $($ skor $>700)$. Analisis data yang digunakan adalah univariat dan analisis bivariat menggunakan uji chi-square dengan tingkat kepercayaan 95\%. Komite etik STIKes Hang Tuah Pekanbaru telah mengeluarkan surat etik dengan Nomor. 293/KEPK/STIKes-HTP/VI/2019.

\section{HASIL DAN PEMBAHASAN \\ Analisis Univariat}

Karakteristik responden mayoritas berusia $<40$ tahun sebanyak 20 orang $(57,1 \%)$. Jenis kelamin perempuan sebanyak 25 orang $(71,4 \%)$, dan pendidikan SD-SMP/Sederajat yaitu sebanyak 28 orang $(80 \%)$. Lima variabel pengetahuan, personal hygiene, kebersihan peralatan, cara penyajian dan lingkungan terhadap hygine dan sanitasi makanan disajikan pada tabel 1 .

Tabel 1. Distribusi Frekuensi Faktor-faktor yang berhubungan dengan hygiene dan Sanitasi Pedagang Makanan Jajanan Murid SD di Pekanbaru

\begin{tabular}{|c|c|c|}
\hline No & Variabel & $f(\%)$ \\
\hline \multirow{3}{*}{1} & Hygiene Sanitasi Makanan & \\
\hline & Rendah $\leq 700$ & $18(51,4 \%)$ \\
\hline & Tinggi $>700$ & $17(48,6 \%)$ \\
\hline \multirow{3}{*}{2} & Pengetahuan & \\
\hline & Rendah & $18(51,4 \%)$ \\
\hline & Tinggi & $17(48,6 \%)$ \\
\hline \multirow{3}{*}{3} & Personal Hygiene & \\
\hline & Rendah & $18(51,4 \%)$ \\
\hline & Tinggi & $17(48,6 \%)$ \\
\hline \multirow{3}{*}{4} & Kebersihan Peralatan & \\
\hline & Kurang Bersih & $16(45,7 \%)$ \\
\hline & Bersih & $19(54,3 \%)$ \\
\hline \multirow{3}{*}{5} & Cara Penyajian & \\
\hline & Kurang Baik & $19(54,3 \%)$ \\
\hline & Baik & $16(45,7 \%)$ \\
\hline \multirow{3}{*}{6} & Lingkungan & \\
\hline & Kurang Baik & $20(57,1 \%)$ \\
\hline & Baik & $15(42,9 \%)$ \\
\hline
\end{tabular}

Tabel 1 menjelaskan terdapat 18 orang $(51,4 \%)$ yang tidak memenuhi standar mutu hygiene dan sanitasi makanan serta berpengetahuan rendah. Pedagang dengan personal hygiene dengan kategori rendah berjumlah 18 orang $(51,4 \%)$. Pedagang dengan kategori kebersihan peralatan yang rendah berjumlah 16 orang $(45,7 \%)$. Cara penyajian pada kategori kurang baik berjumlah 19 orang $(54,3 \%)$, dan pedangang dengan kategori lingkungan yang kurang baik berjumlah 20 orang $(57,1 \%)$.

\section{Analisis Bivariat}

Uji chi square pada analisis bivariat ini digunakan untuk melihat hubungan dari pengetahuan, personal hygiene, kebersihan peralatan, cara penyajian dan lingkungan. terhadap hygiene dan sanitasi makanan seperti terlihat pada Tabel 2.
Berdasarkan uji statistik yang disajikan pada Tabel 2 menunjukkan bahwa $\rho$-value untuk pengetahuan adalah 0,028 POR $(6,240)$, personal higiene 0,026 POR $(6,500)$, kebersihan peralatan 0,011 POR $(8,400)$, cara penyajian 0,028 POR $(6,417)$, dan lingkungan 0,028 POR $(6,240) \leq \alpha(0,05)$ dengan nilai $\mathrm{POR}>1$ artinya pedagang yang pengetahuan rendah, personal higiene, kebersihan peralatan, cara penyajian, dan lingkungan yang rendah berisiko terhadap higienitas makanan. 
Tabel 2. Analisis Statistik Faktor yang Berhubungan dengan Hygiene dan Sanitasi Pada Pedagang Makanan Jajanan Murid SD di Pekanbaru

\begin{tabular}{|c|c|c|c|c|c|c|c|}
\hline \multirow[t]{2}{*}{ No } & \multirow[t]{2}{*}{ Variabel } & \multicolumn{2}{|c|}{$\begin{array}{c}\text { Hygiene dan Sanitasi } \\
\text { Makanan }\end{array}$} & \multirow[t]{2}{*}{ p-value } & \multirow[t]{2}{*}{ POR } & \multicolumn{2}{|c|}{$95 \% \mathrm{CI}$} \\
\hline & & Rendah $\leq 700$ & Tinggi $>700$ & & & Lower & Upper \\
\hline \multirow{3}{*}{1} & Pengetahuan & & & \multirow{3}{*}{$0,028^{*}$} & \multirow{3}{*}{6,240} & \multirow{3}{*}{1,439} & \multirow{3}{*}{27,059} \\
\hline & Rendah & $13(72,2 \%)$ & $5(27,8 \%)$ & & & & \\
\hline & Tinggi & $5(29,4 \%)$ & $12(70,6 \%)$ & & & & \\
\hline \multirow{3}{*}{2} & Personal Higiene & & & \multirow{3}{*}{$0,026^{*}$} & \multirow{3}{*}{6,500} & \multirow{3}{*}{1,467} & \multirow{3}{*}{28,804} \\
\hline & Rendah & $12(75 \%)$ & $4(25 \%)$ & & & & \\
\hline & Tinggi & $6(31,6 \%)$ & $13(68,4 \%)$ & & & & \\
\hline \multirow{3}{*}{3} & Kebersihan Peralatan & & & \multirow{3}{*}{$0,011^{*}$} & \multirow{3}{*}{8,400} & \multirow{3}{*}{1,829} & \multirow{3}{*}{38,568} \\
\hline & Kurang Bersih & $14(73,7 \%)$ & $5(26,3 \%)$ & & & & \\
\hline & Bersih & $4(25 \%)$ & $12(75 \%)$ & & & & \\
\hline \multirow{3}{*}{4} & Cara Penyajian & & & \multirow{3}{*}{$0,028^{*}$} & \multirow{3}{*}{6,417} & \multirow{3}{*}{1,444} & \multirow{3}{*}{28,511} \\
\hline & Kurang Baik & $14(70 \%)$ & $6(30 \%)$ & & & & \\
\hline & Baik & $4(26,7 \%)$ & $11(73,3 \%)$ & & & & \\
\hline \multirow{3}{*}{5} & Lingkungan & & & \multirow{3}{*}{$0,028^{*}$} & \multirow{3}{*}{6,240} & \multirow{3}{*}{1,439} & \multirow{3}{*}{27,059} \\
\hline & Kurang Baik & $13(72,2 \%)$ & $5(27,8 \%)$ & & & & \\
\hline & Baik & $5(29,4 \%)$ & $12(70,6 \%)$ & & & & \\
\hline
\end{tabular}

Ket : * (signifikan)

\section{Hygiene Sanitasi Makanan Jajanan}

Berdasarkan hasil penelitian ini terdapat $51,4 \%$ hygiene sanitasi jajanan masih pada kategori rendah. Berdasarkan hasil pengamatan menunjukkan para pedagang belum memperhatikan pembuangan limbah hasil pengolahan makanan, ketersediaan air bersih belum memadai, air hanya ditaruh di ember yang terbuka tanpa penutup. Makanan jajanan terkadang tidak ditutup sempurna hanya menggunakan kain gorden dan sering terbuka. Penelitian lain di Palembang juga menyebutkan bahwa masih ditemukan $47,8 \%$ responden hygiene sanitasi yang kurang baik. Pada penelitian tersebut menjelaskan bahwa perilaku yang tidak sehat ditunjukkan pedagang ketika menjajakan makanan. Kondisi makanan dalam keadaan terbuka serta lokasi makanan jajanan tersebut berada dipinggir jalan yang dilalui oleh kendaraan-kendaraan bermotor. ${ }^{17}$

Anak-anak sekolah memiliki kecenderungan mengkonsumni makanan jajanan kaki lima di sekolah dibandingkan membawa bekal dari rumah. ${ }^{2}$ Pola makan anak yang kurang teratur, membuat mereka menjadi sangat konsumtif terutama pada makanan jajanan. Aspek negatif yang terjadi adalah keamanan jajanan yang dikonsumsi tidak terjaga dengan baik. ${ }^{18}$

\section{Pengetahuan}

Penelitian ini menyebutkan bahwa terdapat hubungan antara pengetahuan dengan sarana higiene dan sanitasi makanan dan pengetahuan yang rendah tersebut berisiko 6,2 kali untuk tidak menjaga higiene dan sanitasi makanan. Hal ini menunjukkan bahwa pendidikan sangat mempengaruhi pengetahuan pedagang yang rendah dan sangat berperan penting dalam menentukan hygiene dan sanitasi pada makanan. ${ }^{17}$ Penelitian tersebut menjelaskan bahwa mayoritas 31,9\% pedagang tidak sekolah dan tamat Sekolah Dasar. Penelitian lain di DKI Jakarta mengatakan bahwa ada kaitan antara tingkat pendidikan pedagang dengan kebersihan jajanan. Penelitian tersebut menyimpulkan terdapat hubungan yang signifikan antara kebersihan dengan tingkat pendidikan terutama setelah mencapai tingkatan Sekolah Menengah Pertama (SMP). ${ }^{19}$

Faktor yang mendukung dalam pemilihan jajanan sehat adalah pengetahuan, karena pengetahuan responden sangat berhubungan erat dengan kualitas gizi makanan sehat. ${ }^{20}$ Penelitian hasil yang sama juga dilakukan di SD Kota Depok yang menyatakan adanya hubungan pengetahuan tentang pemilihan makanan jajanan dengan perilaku anak dalam memilih makanan jajanan. ${ }^{21}$ Untuk itu diperlukan pengetahuan mengenai jajanan sehat untuk mengetahui baik tidaknya konsumsi jajanan tersebut yang berdampak pada status gizi anak-anak.

\section{Personal Hygiene}

Penelitian ini mengatakan bahwa terdapat hubungan antara personal hygiene responden dengan sarana hygiene dan sanitasi makanan dan berisiko 6,5 kali untuk makanan jajanan tidak higienis. Hal ini menunjukkan bahwa personal hygiene pedagang sangat berperan penting dalam menentukan hygiene dan sanitasi pada makanan. Hasil penelitian ini juga sejalan dengan penelitian di Ciputat Timur yang menjelaskan bahwa penjamah makanan memiliki personal hygiene yang kurang baik sebesar $61,2 \%{ }^{22}$

Tangan yang tidak bersih dan terpapar dengan yang lainnya mengakibatkan pemindahan bakteri dan virus patogen dari tubuh, feses atau sumber lain ke makanan yang disajikan. Kebiasaan tidak mencuci tangan sebelum melayani pembeli merupakan sumber 
kontaminan yang berpengaruh terhadap kebersihan bahan makanan. Biasakan untuk mencuci tangan dengan sabun, menggosok tangan, membilas dengan air mengalir dapat membersihkan kotoran-kotoran yang mengandung kuman dan bakteri. Menjaga kebersihan tangan, rambut, pakaian dan kuku juga termasuk kebersihan perorangan. Menjaga kebersihan kulit di daerah kuku juga merupakan hal yang penting. Sebaiknya para pedagang menggunakan baju celemek dan penutup kepala guna untuk mengurangi risiko munculnya kontaminasi zat kimiawi pada makanan yang terpapar pada makanan sehingga menimbulkan penyakit diare. ${ }^{23-25}$

\section{Kebersihan Peralatan}

Terdapat hubungan antara kebersihan peralatan responden dengan sarana hygiene dan sanitasi makanan dilihat dari nilai POR sebesar 8,400 artinya pedagang dengan kebersihan peralatan rendah berisiko 8,4 kali untuk tidak hygiene. Hal ini terlihat dari proses pencucian peralatan pengolahan makanan tidak menggunakan air mengalir melainkan hanya menggunakan air didalam baskom yang dipakai secara berulang.

Penelitian lain di SD Kelurahan Demang Labar Daun Palembang menjelaskan tentang penggunakan peralatan yang kurang bersih. Penelitian tersebut menjelaskan bahwa pada pedadang menggunakan wadah cuci gelas dan piring hanya dengan satu ember dan itu digunakan seharian selama berdagang. Lalu alat-alat yang sudah dicuci tersebut dibiarkan terbuka. Hal serupa juga ditemukan pada salah satu SDN di Kota Surabaya. Pada penelitian tersebut menjelaskan bahwa proses pencucian peralatan yang digunakan masih pada kategori kurang baik sebanyak $51,67 \% .^{17,26}$

Kebersihan peralatan memiliki hubungan yang bermakna dengan hygiene dan sanitasi makanan, misalnya mencuci peralatan menggunakan air mengalir dan memakai sabun, menghindari pemakaian alat sekali pakai, serta menjaga kebersihan peralatan agar peralatan tetap terjaga kebersihannya. Hal ini menjadi salah satu faktor pendorong untuk hygiene dan sanitasi makanan. Pedagang perlu terus melakukan peningkatan kualitas higiene dan sanitasi makanan dengan cara menyediakan tempat sampah organik dan non organik.

\section{Cara Penyajian Makanan}

Penelitian ini menjelaskan bahwa terdapat hubungan antara cara penyajian responden dengan higiene dan sanitasi makanan dengan nilai $p$-value $<$ $0,05(\mathrm{POR}=6,417)$, artinya pedagang dengan cara penyajian rendah berisiko 6,4 kali untuk tidak higiene. Tempat yang bersih, peralatan yang digunakan bersih, sirkulasi udara dapat berlangsung, penyaji berpakaian bersih dan rapi menggunkan tutup kepala dan celemek menjadi hal yang harus terus dijaga oleh pedagang. Makanan jajanan tersebut tidak ditutup dengan baik. Terkadang hanya ditutup menggunakan plastik tipis, selembar kertas koran atau daun pisang. Ada juga yang menggunakan kain gorden tipis yang hanya sesekali dirapatkan ketika pembeli sedang ramai akibatnya lalat menghinggapi makanan-makanan tersebut.

Penelitian lain di Palembang dan Mataram menjelaskan bahwa menjajakan makanan dalam keadaan terbuka dapat meningkatkan risiko tercemarnya makanan oleh lingkungan, baik melalui udara, debu, bahkan serangga. Penelitian tersebut juga mengatakan bahwa masih terdapat $60,9 \%$ pedagang yang membungkus jajanan mereka menggunakan kertas koran dan kantong kresek yang berwarna. ${ }^{17,27}$

\section{Lingkungan}

Berdasarkan hasil penelitian diketahui bahwa adanya hubungan antara lingkungan responden dengan higiene dan sanitasi makanan $(\mathrm{POR}=6,240)$ artinya pedagang dengan lingkungan rendah berisiko 6,2 kali untuk tidak higienis. Sampah-sapah yang berserakan disekitar dagangan mengakibatkan kondisi lingkungan terlihat kotor dan tidak bersih. Upayakan agar halaman disekitar dagangan selalu kering (tidak becek karena genangan air). Tumpukan sampah mengakibatkan lalat, kecoa, serangga dan tikus dapat berkembang biak. Hal lain yang tidak kalah penting adalah sirkulasi udara dan intensitas cahaya. Bila kondisi sanitasi lingkungan sudah baik maka kualitas makanan yang dihasilkan terjamin keamanannya dan juga sehat. ${ }^{28,29}$

Penelitian lain yang dilakukan di Kota Medan tentang pedagang jajanan siswa SD mengatakan bahwa sekitar $65 \%$ lingkungan makanan jajanan masih pada kategori kurang baik. Untuk meningkatkan hygiene makanan jajanan penelitian tersebut menyarakan untuk lebih memperhatikan kebersihan lingkungan saat melakukan pengolahan makanan. $^{30}$

\section{SIMPULAN}

Faktor pengetahuan, personal hygiene, kebersihan peralatan, cara penyajian dan lingkungan pedagang makanan jajanan berhubungan signifikan dengan hygiene dan sanitasi makanan jajanan siswa. Faktor kebersihan peralatan merupakan variabel paling dominan pada penelitian ini.

Perlu koordinasi. peran aktif dan pengawasan berkelanjutan dari pihak sekolah bersama-sama dengan pemerintah daerah setempat dalam penerapan standar kebersihan, keamanan dan makanan yang sehat bagi siswa Sekolah Dasar di Kota Pekanbaru. Siswa perlu diberikan informasi dan sosialisasi kesehatan dengan menggunakan media-media edukatif. Pedagang makanan jajanan perlu pelatihan atau sosialisasi penerapan standar hygiene dan sanitasi makanan jajanan. Perlu pengecekan berkala oleh Badan Pengawasan Obat dan Makanan (BPOM) setempat. 


\section{UCAPAN TERIMA KASIH}

Kami mengucapkan terima kasih kepada semua pihak yang berpartisipasi membantu kelancaran penelitian ini antara lain: seluruh responden pedagang makanan jajanan, Kepala Sekolah, guru dan staf SD. Ketua Lembaga Penelitian dan Pengabdian Masyarakat (LPPM) STIKes Hang Tuah Pekanbaru.

\section{DAFTAR PUSTAKA}

1. Iklima, N. Gambaran Pemilihan Makanan Jajanan Pada Anak Usia Sekolah Dasar. Jurnal Keperawatan BSI, 2017, 5(1): 8-17.

2. Almanfaluthi, M.L. Budi, M.H. Hubungan Antara Konsumsi Jajanan Kaki Lima Terhadap Penyakit Diare Pada Anak Sekolah Dasar. Medisains: Jurnal Ilmiah Ilmu-ilmu Kesehatan, 2015, 13(3): 58-65

3. Suherman, Aini. F.Q. Analisis Kejadian Diare pada Siswa di SD Negeri Pamulang 02 Kecamatan Pamulang Tahun 2018. Jurnal Kedokteran dan Kesehatan, 2019, 15(1): 199208. https://doi.org/10.24853/jkk.15.2.199-208

4. Gultom,. M.K.M, Onibala, F. Bidjuni, H. Hubungan Konsumsi Makanan Jajanan Dengan Diare Pada Anak di SDN 3Gogagoman Kecamatan Kotamobagu Barat Kota Kotamobagu. 2018. e-Journal Keperawatan (eKp) 6(1): 1-7

5. Nurbiyati,. T. Wibowo, A.H. Pentingnya Memilih Jajanan Sehat Demi Kesehatan Anak. Jurnal Inovasi dan Kewirausahaan, 2014, 3(3): 192-196

6. Selinaswati. Fitriani.E. Peran Sekolah Dalam Antisipasi Keracunan Pangan Jajanan Anak Sekolah-PJAS (Studi Kasus Tiga SD di Air Tawar Timur Padang Sumatera Barat). Jurnal Socius: Journal of Sociology Research and Education, $\quad 2017, \quad 4(2)$ : $126-133$. https://doi.org/10.24036/scs.v4i2.18

7. Astuti, windy, Anastasia, H., Ratianingsih, R., Puspitaa, J. W., \& samarang, samarang. Deteksi Penyakit Schistosomiasis Melalui Identifikasi Telur Cacing Pada Feses Manusia Menggunakan Probabilistic Neural Network (PNN). Jurnal Vektor Penyakit, 2020, 14(1): 49-56. https://doi.org/10.22435/vektorp.v14i1.2013

8. Nuruzzaman, H. Syahrul F. Analisis Risiko Kejadian Demam Tifoid Berdasarkan Kebersihan Diri dan Kebiasaan Jajan Di Rumah. Jurnal Berkala Epidemiologi, 2016, 4(1):74-86

9. Syafirah, S., \& Andrias, D. R. Higiene Penjamah Makanan Dan Sanitasi Kantin Sekolah Dasar Negeri Di Kecamatan Mulyorejo, Surabaya. Media Gizi Indonesia, 2017, 10(2), 111-116.

10. Ding Z, Zhai Y, Wu C, Wu H, Lu Q, Lin J, He F. Infectious diarrheal disease caused by contaminated well water in Chinese schools: A systematic review and meta-analysis. J $\begin{array}{llll}\text { Epidemiol. } 2017 \text { Jun;27 (6):274-281. doi: } & \end{array}$ 10.1016/j.je.2016.07.006. Epub 2017 Apr 27. PMID: 28457602; PMCID: PMC5463023.

11. Fischer Walker CL, Sack D, Black RE. Etiology of Diarrhea in Older Children, Adolescents, and Adults: A Systematic Review. PLoS Negl Trop Dis. 2010 Aug 3;4(8): e768. DOI: 10.1371/journal.pntd.0000768. PMID: 20689809; PMCID: PMC2914743

12. World Health Organization. WHO Estimates of the Global Burden of Foodborne Diseases. Foodborne Disease Burden Epidemiology Reference Group 2007-2015; 2013

13. BPOM Republik Indonesia. Laporan Badan Milik Negara Badan Pengawas Obat dan Makanan Tahun Anggaran 2015. Jakarta; 2016

14. Rauf, R. Sanitasi pangan \& HACCP. Penerbit Graha Ilmu Ed 1, Yogyakarta; 2013

15. Menteri Kesehatan Republik Indonesia. Keputusan Menteri Kesehatan Republik Indonesia Nomor 942/MENKES/ SK/VII/ 2003, Tentang Pedoman Persyaratan Hygiene Sanitasi Makanan Jajanan. 2003

16. Dinas Kesehatan Provinsi Riau. Profil Kesehatan Provinsi Riau, 2017.

17. Agustina, F, Pambayun, R \& Febry, F. Higiene dan Sanitasi Pada Pedagang Makanan Jajanan Tradisional di Lingkungan Sekolah Dasar Di Kelurahan Demang Lebar Daun Palembang. Jurnal Ilmu Kesehatan Masyarakat, 2010, 1(1): 53-63

18. Sinthamurniwaty. Faktor-Faktor Risiko Kejadian Diare Akut Pada Balita (Studi Kasus di Kabupaten Semarang). Program Pasca Sarjana Universitas Diponegoro Semarang, Tesis, 2006

19. Marsaulina, Irnawati, Study Tentang Pengetahuan Perilaku Dan Kebersihan Penjamah Makanan Pada Tempat Umum Pariwisata Di DKI Jakarta (TMII, TIJA, TMR). Fakultas Kesehatan Masyarakat Universitas Sumatera Utara. 2004; 1-16 https://repository.usu.ac.id/bitstream/handle/123 $\underline{456789 / 3748 / \text { fkmirnawati.pdf;jsessionid=D8869 }}$ 368E4173ECF3358F1D589DFAA5D?sequence $=1$

20. Febryanto, M. A. B. Hubungan Antara Pengetahuan dan Sikap dengan Perilaku Konsumsi Jajanan di MI Sulaimaniyah Jombang: Jurnal Ilmiah Kebidanan (Scientific Journal of Midwifery), 2017, 3(1): 51-59.

21. Triasari, R. Hubungan Pengetahuan dan Sikap Mengenai Jajanan Aman dengan Perilaku Memilih Jajanan Pada Siswa Kelas V SD Negeri Cipayung 2 Kota Depok. Program Studi Ilmu Keperawatan Fakultas Kedokteran dan Ilmu Kesehatan Universitas Islam Negeri Syarif Hidayatullah Jakarta, Skripsi. 2015

22. Eka Lestari Sitepu. Analisis Personal Hygiene Pada Penjual Makanan Tradisional Gado - Gado Di Kelurahan Pisangan, Cempaka Putih Dan 
Cireundeu Ciputat Timur Tahun 2015. Universitas Islam Negeri (UIN) Syarif Hidayatullah. Skripsi https://repository.uinjkt.ac.id/dspace/bitstream/1 23456789/29636/1/Eka\%20Lestari\%20Sitepufkik.pdf

23. Ferllando, H.T dan Asfawi, S., Hubungan Antara Sanitasi Lingkungan dan Personal Hygiene Ibu dengan Kejadian Diare pada Balita di Wilayah Kerja Puskesmas Mangkang, Jurnal Visikes 2016, 14(2): 131-138.

24. Wulansari, A., Setiawan, B., \& Sinaga, T. Penyelenggaraan Makanan Dan Tingkat Kepuasan Konsumen Di Kantin Zea Mays Institut Pertanian Bogor. Jurnal Gizi Dan Pangan, $2014, \quad 8(2)$ : 151-158. https://doi.org/10.25182/jgp.2013.8.2.151-158

25. Islamy,. G.P. Sumarmi, S. \& Farapti. Analisis Higiene Sanitasi dan Keamanan Makanan Jajanan di Pasar Besar Kota Malang. Research Study, Amerta Nutr. 2018, 2 (1): 29-36. https://doi.org/10.20473/amnt.v2i1.2018.29-36

26. Susanna, D., Hartono, B. Pemantauan Kualitas Makanan Ketoprak Dan Gado-Gado Di
Lingkungan Kampus Ui Depok, Melalui Pemeriksaan Bakteriologis. Jurnal Makara, Seri Kesehatan, 2003, 7(1), 21-28.

27. Chandradewi, AASP. Darawati, Yuniati. M.N.K. Nilai Gizi Dan Higiene Sanitasi Makanan Jajanan Yang Dijual Di Kantin Sekolah Dasar di Kota Mataram. Jurnal Kesehatan Prima. 2011, 5(1): 670-683

28. Restuatuti, T. Handayani, \& Ernalia, Y. Penilaian Status Gizi Anak Usia Sekolah Dasar dan Pelatihan Pangan Jajanan Sehat Anak Sekolah Dasar Di Pekanbaru. Lembaga Pengabdian Masyarakat Universitas Riau. Laporan Pengabdian Kepada Masyarakat. 2012.

29. Swamilaksita, P. D., \& Pakpahan, S. R. FaktorFaktor yang Mempengaruhi Penerapan Higiene Sanitasi di Kantin Universitas Esa Unggul Tahun 2016. Jurnal Gizi Kesehatan Masyarakat, 2016, 8(2), 1-9.

30. Sumbayak, M.P. Evaluasi Hygiene Makanan Jajanan Siswa Sekolah Dasar Negeri 064972 Kota Medan Tahun 2020. Journal of Healthcare Technology and Medicine. Universitas Ubudiyah Indonesia, 2021, 7(1); 114-127 